\title{
CLINICAL AND MORPHOLOGICAL COMPARISON OF RESPIRATORY FAILURE IN PATIENTS WITH COVID-19 WHO DIED UNDER DIFFERENT OPTIONS OF RESPIRATORY SUPPORT
}

\author{
Vita Skoryk, Volodymyr Korsunov, Tetiana Bocharova, Valentina Maslova, \\ Pavlo Nartov
}

The aim. Based on the study of the effect of invasive mechanical ventilation and NIV in the CPAP mode on the pathomorphosis of lung damage in patients with HRF caused by SARS-nCoV-2 and deaths in intensive care unit (ICU), determine the safest method of respiratory support.

Materials and methods. The study included morphological material from 20 patients with HRF caused by SARS-nCoV2 (COVID-19) who died in ICU. Group 1 included patients who received non-invasive lung ventilation in CPAP mode through a face mask $(n=10)$, group 2 - patients who underwent invasive ventilation $(n=10)$. The prepared sections, $5 \mu \mathrm{m}$ thick, were stained according to the Van Gizon method. Photomicrographs were taken using Zeiss ZENliteimaging. Data are presented as M [25-75] and P \pm Sp. Statistical analysis of the results was performed using the program "Statistica 10". Significance of differences in indicators was assessed using the nonparametric Wilcoxon test, the parametric Student's test. The results were considered reliable at values of $p<0.05$.

Results The morphological structure of the lungs of patients of group 1 corresponded to the exudative phase of DAD with severe edematous-hemorrhagic syndrome, signs of interstitial pneumonia with desquamation of alveolocytes and the formation of hyaline membranes. In patients of group 2 in the lung tissue there was a picture of the proliferative phase of DAD with signs of interstitial pneumonia, and the development of focal fibrosing alveolitis. Thus, invasive mechanical ventilation, can accelerate the development of irreversible processes in the lungs in the form of fibrosing alveolitis and promote the formation of ventilator-associated pneumonia

Conclusions. CPAP NIV is a promising method of respiratory support in patients with ARDS caused by SARS-nCoV-2 virus (COVID-19), which needs further study

Keywords: SARS-nCoV-2, COVID-19, hypoxemic respiratory failure, acute respiratory distress syndrome, respiratory support, non-invasive lung ventilation

(C) The Author(s) 2021

This is an open access article under the Creative Commons CC BY license hydrate

How to cite:

Skoryk, V., Korsunov, V., Bocharova, T., Maslova, V., Nartov, P. (2021). Clinical and morphological comparison of respiratory failure in patients with covid-19 who died under different options of respiratory support. ScienceRise: Medical Science, 4 (43), 3-12. doi: http://doi.org/10.15587/25194798.2021.238093

\section{Introduction}

Hypoxemic respiratory failure (HRF) is the main cause of death in patients in the intensive care unit (ICU) with severe COVID-19. According to a study by Q. Ruanetal, HRF is cited as the leading cause of death in $88 \%$ of patients with COVID-19 [1]. At the beginning of the coronavirus pandemic, early intubation and mechanical ventilation were thought to have a positive effect on survival [2]. However, according to recent studies in the United Kingdom, the United States and China, COVID19 mortality in patients undergoing invasive mechanical ventilation was extremely high at 65-92\% [3-5].

Therefore, the search for alternative respiratory support was aimed at elucidating the possibilities of noninvasive techniques. At present, more and more attention is paid to the methods of non-invasive lung ventilation (NIV) [6]. NIV has significant advantages over traditional mechanical ventilation - it does not require the imposi- tion of artificial airways (intubation tube, tracheostomy), improves patient comfort, reduces the need for sedatives, and significantly reduces the risk of direct respiratory damage and nosocomial infections [7, 8]. However, the place of NIV in the treatment of HRF in patients with COVID-19 remains the subject of debate.

At the same time, in real clinical practice NIV is used almost everywhere in the treatment of severe forms of COVID-19. The proportion of patients in need of NIV ranges from 11 to $96 \%$.The most common NIV is used in China (average - $62 \%$ ), less often - in North America $(20 \%)$ [9].

The main goal of therapy in HRF is to improve oxygenation, reduce respiration, and reduce shortness of breath [10]. The first can usually be achieved by using higher levels of positive end-expiratory pressure (PEEP) to attract (recruit) unventilated or poorly ventilated alveoli into the ventilation process [11]. Increasing PEEP 
is able to maintain the alveoli in the open state, increasing the functional residual capacity, reducing the ventilation-perfusion imbalance and the shunt and thereby improving oxygenation. In addition, the use of PEEP stabilizes the airways and reduces the heterogeneity of lung volume distribution [10]. NIV also reduces respiratory muscle function.

In addition, the use of NIV CPAP in patients with pneumonia and severe HRF has been shown to reduce the risk of tracheal intubation and mechanical ventilation [12].

Unlike patients requiring invasive ventilation for whom protective ventilation protocols have been developed, there are currently no similar guidelines for NIV to reduce the risk of ventilator-induced lung injury. This may be one of the main problems with the use of NIV in patients with HRF. Among the main discussion issues, which are based on the understanding of pathophysiological processes in HRF, and have an impact on its further course, are considered some options for lung damage during respiratory therapy. These are the well-known phenomena VILI - ventilator induced lung injury and PSILI - patient self-inflicted lung injury. It cannot be ruled out that VILI is one of the reasons for the high proportion of adverse outcomes in patients with invasive pulmonary ventilation, while P-SILI - damages the lungs during both self-breathing and auxiliary ventilation with positive inspiratory pressure. With regard to CPAP technology, some authors note that it can both reduce the negative effects of P-SILI and reduce the need for invasive ventilation, thus preventing the development of VILI [13]. It has also been shown that the ineffectiveness of NIV is an independent risk factor for death in patients with COVID-19, although careful selection of patients is likely to reduce this risk [15].

During the study of coronavirus disease, the results of only a small number of studies on the effectiveness of HIV in GDN in patients with COVID-19 are available [16-22].

It is noteworthy that in the presented studies, patients who are on NIV are often outside the ICU. This practice reflects current trends, according to which, with the accumulation of experience in the use of NIV, it is possible to use it not only in ICU, but also in specialized departments, which have less monitoring capacity and a lower ratio of nurses to patients [23].

Experience gained during intensive care of patients with COVID-19 demonstrates that NIV cannot be a sufficient method of respiratory support for all patients. In some of them, NIV can temporarily improve oxygenation and reduce respiratory function, but does not change the progression of the disease and as a result does not prevent intubation of the trachea and mechanical ventilation. Unfortunately, today there are no reliable markers of disease progression against the NIV.

To determine the optimal tactics for respiratory support, large randomized controlled trials are currently being conducted to evaluate the effectiveness of NIV in patients with COVID-19. Joining the discussion on the advantages and disadvantages of invasive and noninvasive respiratory support, we formulated a hypothesis about the possibility of studying the pathomorphosis of changes in the bronchopulmonary system as a tool capable of approaching the solution of this complex dilemma.
Although the pathomorphological changes in the lungs of patients who died of COVID-19 are well described, we have not been able to find a comparison of the pathomorphosis of the lungs depending on the type of respiratory support in the literature. Therefore, this is the purpose of our study.

The aim of the research. Based on the clinical and morphological comparison of the course of respiratory failure in patients with HRF caused by SARS-nCoV-2 and those who died in intensive care (ICU), to determine the most promising method of respiratory support.

\section{Materials and methods}

The study was conducted for the period June 2020 February 2021 at the clinical base of the Department of Anesthesiology, Pediatric Anesthesiology and Intensive Care of the Kharkiv Medical Academy of Postgraduate Education in the Intensive Care Unit of the Kharkiv Regional Council "Regional Clinical Infectious Diseases Hospital".

The work was done in accordance with the Code of Ethics of the World Medical Association (Declaration of Helsinki). The work is allowed by the Biotic Commission of the Kharkiv Medical Academy of Postgraduate Education No. 1, minutes 11.02.2021. All patients included in the study provided written informed consent during hospitalization.

The diagnosis of coronavirus disease was confirmed by PCR isolation of SARS-CoV-2 RNA from nasopharyngeal lavage. Verification of pneumonia was performed by computed tomography or chest radiography. The diagnosis of ARDS was established according to the Berlin criteria. All patients underwent clinical blood tests, biochemical studies to assess the severity of COVID-19 and to determine the status of vital organs and systems. formula:

Body mass index (BMI) was calculated by the

BMI=body mass / height $2\left(\mathrm{~kg} / \mathrm{m}^{2}\right)$.

Monitoring of patients during intensive care included electrocardiography to determine heart rate (HR), measurement of mean blood pressure (MAP by oscillometric method and pulse oximetry $\left(\mathrm{SpO}_{2} \%\right)$ (monitors Comen, Mindray iMEC12, BioMed 800).

The concentration of lactate dehydrogenase (LDH) was determined by kinetic method. The concentration of C-reactive protein was determined by the turbidimetric method (Biosystems kits, Spain). To monitor the state of the hemostasis system, D-Dimer was determined by ELISA (Vector-Best kits, Ukraine). The level of interleukin 6 (IL-6) was determined by enzyme-linked immunosorbent assay (eBioscience kits, USA). All biochemical studies were performed on a biochemical analyzer "Chemray 120 Mindray" (PRC).

All patients underwent NIV through a tight-fitting face mask with Newport E 360t, Resvent RS 300, Monnal t75, Graph Net and Extend XT with assessment of ventilation parameters and pulmonary mechanics: $\mathrm{Vt}$ (ml), MV (1/min), f (for $1 \mathrm{~min}$ ), Pin $\left(\mathrm{cm} \mathrm{H}_{2} \mathrm{O}\right)$, Pmean $\left(\mathrm{cm} \mathrm{H}_{2} \mathrm{O}\right)$, PEEP $\left(\mathrm{cm} \mathrm{H}_{2} \mathrm{O}\right), \mathrm{FiO}_{2}(\%)$ using graphics monitors. 

formula:

The saturation index (OSI) was calculated by the

$$
\mathrm{OSI}=\left(\mathrm{FiO}_{2} * \mathrm{Pmean}^{* 100}\right) / \mathrm{SpO}_{2},
$$

where $\mathrm{FiO}_{2}$ is the oxygen fraction in the gas mixture, Pmean is the average airway pressure.

The ROX index was determined by the formula:

$$
\mathrm{ROX}=\left(\mathrm{SpO}_{2} / \mathrm{FiO}_{2}\right) / \mathrm{RR},
$$

where $R R$ is the frequency of respiratory movements [12].

Intensive care of patients was carried out according to the relevant guides of the Ministry of Health of Ukraine and included the anticoagulants, corticosteroids, infusion therapy of restrictive type, antibacterial drugs according to indications, use of sympathomimetics and sedatives as needed, treatment of comorbidities (coronary heart disease, hypertension, and diabetes) [24-28].

In case death, a pathomorphological study was performed. It was performed at the Department of Pathological Anatomy of Kharkiv National Medical University. The study included lung tissue samples from 20 patients with severe SARS-nCoV-2 (COVID-19) with bilateral pneumonia and acute respiratory distress syn- drome (ARDS) who died from various types of respiratory therapy. Pieces of lung tissue taken during autopsy were fixed in $10 \%$ formalin, passed through alcohols in increasing concentration and poured into paraffin. The prepared sections, $5 \mu \mathrm{m}$ thick, were stained with hematoxylin-eosin and picrofuxin according to the Van Gizon method. Histological examinations were performed using a microscope Zeiss Axioscope 40 FL, HBO 50. Photomicrographs were taken using the program Zeiss ZEN liteimaging.

Data are presented as M [25-75] and $\mathrm{P} \pm$ Sp. Statistical analysis of the results was performed using the program "Statistica 10". Significance of differences in indicators was assessed using the nonparametric Wilcoxon test and the parametric Student's test. The results were considered reliable at values of $\mathrm{p}<0.05$.

\section{Results}

The study included morphological material from 20 patients, which were divided into two groups. Group 1 included patients who received non-invasive lung ventilation in CPAP mode through a face mask $(n=10)$, group 2 included patients who underwent lung protective invasive lung ventilation in PCV mode through the endotracheal tube $(n=10)$. According to age and anthropometric data, patients did not differ significantly between groups $(\mathrm{p}<0.05)$ (Table 1).

General characteristics of patients Me [25-75]

Table 1

\begin{tabular}{|c|c|c|}
\hline Indicator & Group 1 & Group 2 \\
\hline Age, years & $64.0[56.0-74.0]$ & $70.0[66.0-82.0]$ \\
\hline BMI, $\mathrm{kg} / \mathrm{m}^{2}$ & $32.7[28.7-34.9]$ & $31.9[25.1-39.2]$ \\
\hline
\end{tabular}

At hospitalization to ICU all patients underwent a clinical blood test (Table 2). In patients of group 1 the indicators were within normal values, in group $2-$ moderate leukocytosis, which can be explained by the presence of artificial airways and faster accession of bacterial infection. In the dynamics, on the 4th day in patients group 1 and patients of group 2 in the clinical analysis of blood there was an increase in the number of White blood cells (Table 3).

Biochemical markers of the severity of COVID19 at the time of hospitalization to ICU were also determined in patients (Table 4). Elevations in LDH, CRP, IL-6, and D-dimer with a predisposition to hypoalbuminemia were observed in the groups.

Table 2

Changes in the clinical analysis of blood of patients at the time of hospitalization Me [25-75]

\begin{tabular}{|c|c|c|}
\hline Indicator & Group 1 & Group 2 \\
\hline $\mathrm{Hb}, \mathrm{g} / \mathrm{L}$ & 129.0 & 129.5 \\
& {$[122.5-13.0]$} & 4.5 \\
& 4.2 & {$[3.5-4.6]$} \\
\hline \multirow{2}{*}{$\mathrm{RBC} * 10^{12} / \mathrm{L}$} & {$[4.1-4.4]$} & 0.4 \\
& 0.4 & {$[0.3-0.4]$} \\
\hline $\mathrm{Ht}$ & {$[0.3-0.4]$} & 247.0 \\
\hline $\mathrm{PLT}, * 10^{9} / \mathrm{L}$ & 174.0 & {$[202.0-319]$.} \\
\hline White blood cells, $\times 10^{9} / \mathrm{L}$ & {$[131.5-200.5]^{*}$} & 14.4 \\
& 7.2 & {$[8.6-1.6]$} \\
\hline \multirow{2}{*}{ Neutrophils, $\%$} & {$[5.9-10.2]^{*}$} & {$[85.5$} \\
\hline Lymphocytes, $\%$ & 85.0 & {$[8.01 .0]$} \\
\hline
\end{tabular}

Note: ${ }^{*}-p<0.05$ the significance of the differences between groups 1 and 2 at the time of hospitalization 
Changes in the clinical analysis of blood on the 4th day of Me [25-75])

\begin{tabular}{|c|c|c|}
\hline Indicator & Group 1 & Group 2 \\
\hline Hb. g/L & 132.0 & 118.2 \\
& {$[126.0-152.0]$} & $41.0-128.0]$ \\
\hline RBC $* 10^{12} / \mathrm{L}$ & 4.3 & {$[3.8-4.4]$} \\
\hline Ht & {$[4.1-4.9]$} & 0.4 \\
& {$[0.4$} & {$[0.3-0.4]$} \\
\hline PLT. $* 10^{9} / \mathrm{L}$ & {$[0.3-0.4]$} & 271.0 \\
\hline White blood cells. $\times 10^{9} / \mathrm{L}$ & 253.0 & {$[203.0-331.0]$} \\
\hline Neutrophils. $\%$ & {$[120.0-303.0]^{*}$} & 12.3 \\
& {$[9.8-13.1]^{*}$} & {$[9.1-19.1]$} \\
\hline Lymphocytes. $\%$ & {$[91.0$} & 92.0 \\
\hline
\end{tabular}

Note: ${ }^{*}-p<0.05$ - the significance of the differences between groups 1 and 2 on the $4^{\text {th }}$ day

Table 4

Comparative characteristics of biochemical data in patients of the examined groups Me [25-75]

\begin{tabular}{|c|c|c|}
\hline Indicator & Group 1 & Group 2 \\
\hline LDH. u/L & 1262.0 & 1259.5 \\
& {$[1156.0-1491.0]$} & 218.8 \\
& 172.2 & {$[63.1-299.4]$} \\
\hline C-reactive protein. g/L & {$[62.2-262.8]$} & 0.4 \\
& 0.4 & {$[0.2-1.4]$} \\
\hline Procalcitonin. $\mathrm{ng} / \mathrm{mL}$ & {$[0.3-0.7]$} & 80.0 \\
\hline IL-6. $\mathrm{pg} / \mathrm{mL}$ & 58.0 & {$[48.0-119.0]$} \\
\hline D-dimer. $\mathrm{ng} / \mathrm{mL}$ & {$[40.0-129.0]$} & 895.5 \\
& 1047.0 & {$[450.0-2775.5]$} \\
\hline Albumin. $\mathrm{g} / \mathrm{L}$ & {$[869.0-3100.0]$.} & 33.6 \\
& 32.1 & {$[30.7-35.2]$} \\
\hline
\end{tabular}

Thus, the data obtained in the patients of the examined groups allow to state the severe course of coronavirus disease with the development of a hyperinflammatory response ("cytokine storm").

In both groups, OSI scores corresponded to severe ARDS (OSI $\geq 12.3$ ). Importantly, in group 2, this figure was significantly higher, which can be explained by the predicted higher Pmean during invasive ventilation. The ROX index was calculated to determine the need to start invasive lung ventilation in group 1 and was 3.3 [3.13.5]. It is important to note that when using different modes of respiratory support, patients in the groups achieved the target levels of saturation (Table 5).

The initial level of $\mathrm{FiO}_{2}$ and PEEP in the groups did not differ significantly $(p>0.05)$. The level of mean and peak airway pressure was significantly higher in group $2(\mathrm{p}<0.05)$, due to the use of invasive ventilation in PCV mode (Table 6).

Table 5

Characteristics of the severity of respiratory failure in patients of the examined groups at the time of hospitalization Me [25-75]

\begin{tabular}{|c|c|c|}
\hline Indicator & Group 1 & Group 2 \\
\hline OSI & 12.8 & 17.4 \\
& {$[10.6-14.1]^{*}$} & {$[15.9-19.1]$} \\
\hline $\mathrm{SpO}_{2} . \%$ & 94.0 & 94.0 \\
& {$[92.0-96.0]$} & {$[93.0-97.0]$} \\
\hline
\end{tabular}

Note: ${ }^{*}-p<0.05$ the significance of the differences between groups 1 and 2 
Main indicators of respiratory mechanics in groups of patients at the beginning of respiratory support Me [25-75]

\begin{tabular}{|c|c|c|}
\hline Indicator & Group 1 & Group 2 \\
\hline $\mathrm{RR}, \mathrm{min}^{-1}$ & 30.0 & 15.0 \\
& {$[28.0-31.0]^{*}$} & {$[14.0-16.0]$} \\
\hline $\mathrm{MV}, \mathrm{L} / \mathrm{min}$ & 18.1 & 7.7 \\
& {$[16.7-19.3]^{*}$} & {$[6.1-8.9]$} \\
\hline \multirow{2}{*}{$\mathrm{FiO}_{2}, \%$} & 100.0 & 100.0 \\
& {$[90.0-100.0]$} & {$[90.0-100.0]$} \\
\hline \multirow{2}{*}{$\mathrm{PEEP}, \mathrm{cm} \mathrm{H}_{2} \mathrm{O}$} & 12.0 & 13.0 \\
& {$[11.0-12.0]$} & {$[12.0-14.0]$} \\
\hline Pmean, $\mathrm{cm} \mathrm{H}_{2} \mathrm{O}$ & 11.4 & 16.5 \\
\hline \multirow{2}{*}{ Ppik, $\mathrm{cm} \mathrm{H}_{2} \mathrm{O}$} & {$[11.0-12.0]^{*}$} & {$[14.9-17.2]$} \\
\hline
\end{tabular}

Note: ${ }^{*}-p<0.05$ the significance of the differences between groups 1 and 2

The median time of hospitalization of patients with ICU was calculated: patients of group 1 were hospitalized for 11.5 [8-13] days, and group 2 - for 11 (8-16) days. The median duration of stay in ICU (respiratory support) was 7 (4-14) days in group 1 and 7.5 (5-10) days in group 2.

The morphological structure of the lungs of patients in group 1 corresponded to the exudative diffuse alveolar damage (DAD) with severe edema-hemorrhagic syndrome, signs of interstitial pneumonia with desquamation of alveolocytes and the formation of hyaline membranes. It should be noted that despite a long period of treatment, the morphological picture in the lungs corresponded to the early alveolar phase of diffuse alveolar damage, signs of organized interstitial pneumonia with the formation of fibrosing alveolitis were observed in only 1 patient. Lung tissue is diffusely compacted, dark cherry color, with areas of dystelectasis, massive drainage hemorrhages and hemorrhagic infarctions. In branches of pulmonary arteries and veins of various caliber multiple parietal, in places obturating thrombi and thromboembolisms were defined.

Microscopically, in all observations in the lung tissue is determined by a pronounced infiltrative edema with the formation of polymorphic cell exudate with impurities of lymphocytes, plasma cells, monocytes and odic neutrophils, as well as a large number of erythrocytes (Fig. 1).

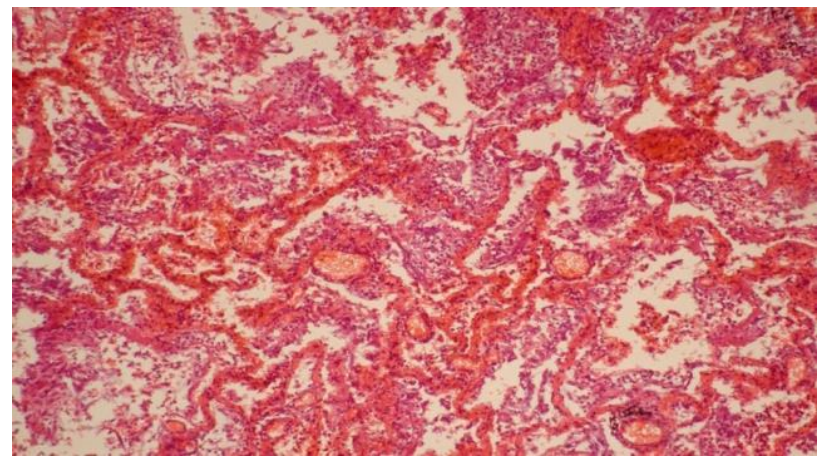

Fig. 1. Polymorphic cell exudate in the lumen of the alveoli, sharp plethora of pulmonary arteries of various calibers and capillaries of the interalveolar septa. Hematoxylin and eosin staining, magnification $\times 100$
In most cases $(80 \pm 13 \%)$ eosinophilic masses adjacent to the walls of the In alveoli were found, which sometimes completely lined the alveolar membranes and forming typical hyaline membranes, sometimes with exfoliation of free alveoli in the lumen of the alveoli, and sometimes phagocytes (Fig. 2).

In some observations in the lumen of the alveoli revealed clusters of desquamated alveolar epithelium with signs of metaplasia, proliferation of type II alveolocytes (Fig. 3).

In $80 \pm 13 \%$ of observations in the thickened edema alveolar membranes revealed mononuclear infiltration with a large number of lymphocytes, plasma cells and macrophages (Fig. 4).

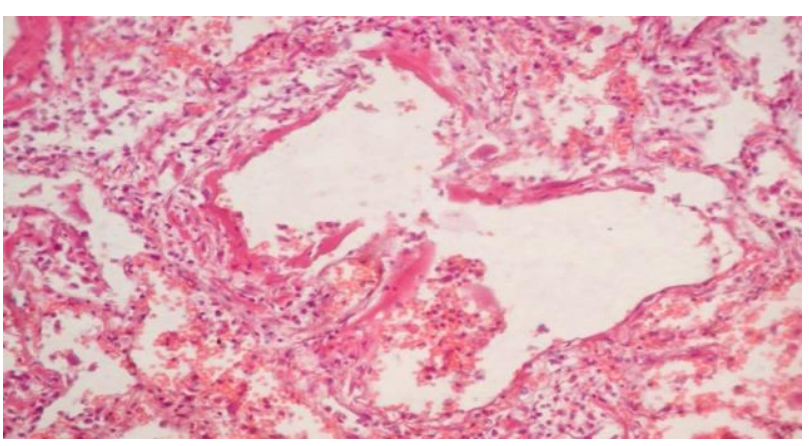

Fig. 2. Lympho-plasma exudate with impurities of macrophages, erythrocytes and fibrin in the lumen of the alveoli with the formation of hyaline membranes. Staining with hematoxylin and eosin, magnification $\times 100$

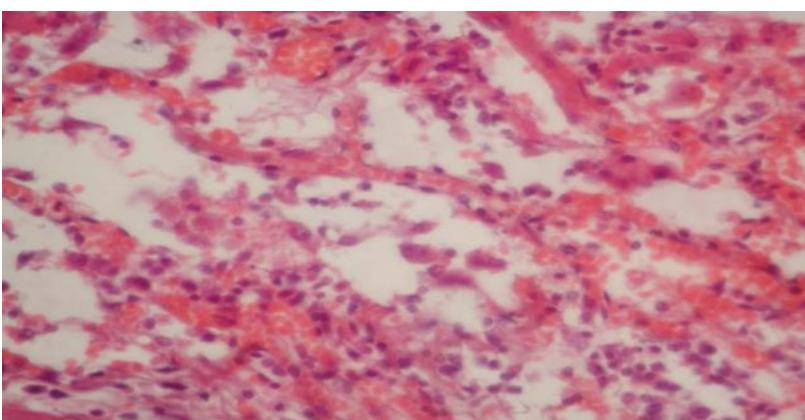

Fig. 3. Plethora of capillaries of interalveolar septa, in the lumen of alveoli clusters of desquamated alveolocytes and alveolar macrophages. Hematoxylin and eosin staining, magnification $\times 100$ 


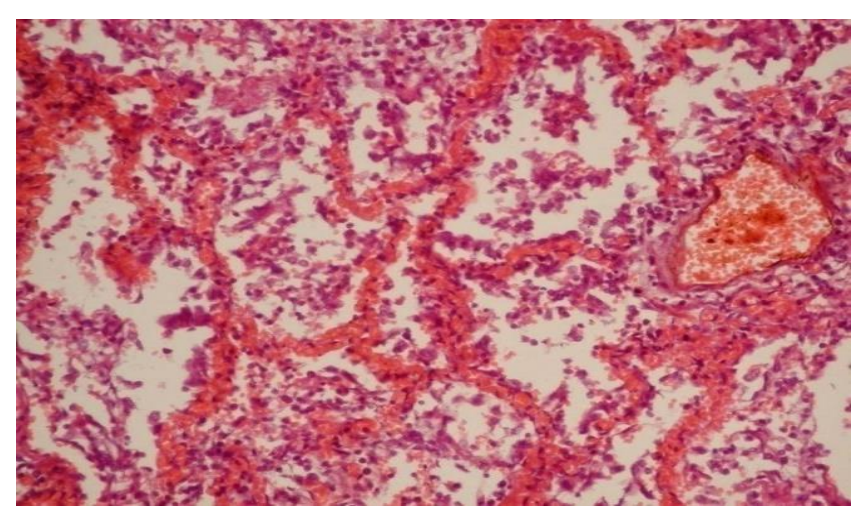

Fig. 4. Thickening of the interalveolar septa due to mononuclear infiltration with impurities of erythrocytes,

sharply full-blooded microcirculatory tract, fibrin clot in the stage of formation in the lumen of the pulmonary artery. Hematoxylin and eosin staining, magnification $\times 100$

Against the background of a pronounced plethora of capillaries of the membranes, as well as branches of the pulmonary veins and arteries, more fibrin clots were detected. The expressed alveolar and hemorrhagic syndrome with existence of perivascular, intraalveolar and intraalveolar hemorrhages with formation of hemorrhagic heart attacks was defined in all supervision.

In patients of group 2 in the structure of lung tissue formed a proliferative phase of DAD with signs of organized interstitial pneumonia, thickening of the alveolar membranes due to mononuclear infiltration and interstitial fibrosis with the development of focal fibrosing alveolitis. The lung tissue was diffusely compacted, almost airless, on the surface and in the section of brown color, with foci of seals of grayish-yellow color, mainly in the lower parts of the lungs, sometimes merging with each other. Focal hemorrhages, in places hemorrhagic heart attacks were defined. In the pulmonary arteries and veins, numerous blood clots and thromboembolism. On the pleura - fibrin overlays were determined in places, in some observations in the pleural cavities there was an accumulation of fibrinous-purulent exudate.

Microscopically in $90 \pm 10 \%$ of observations the sharp plethora of a microcirculatory channel, and also pulmonary arteries and veins of various caliber with formation of a large number of fibrin and clots in a stage of the organization which in places obturate gleams of vessels is defined. Large areas of intraalveolar hemorrhage and hemorrhagic infarction were detected (Fig. 5).

In $87.5 \%$ of observations in the lumens of the alveoli revealed fluid accumulation with the presence of polymorphic cell exudate, erythrocytes and large amounts of fibrin in the organization stage (Fig. 6).

Large fields of obliterative productive bronchiolitis and foci of pneumonia in the stage of organization, tissue with the development of fibrosing alveolitis (Fig. 7).

In $10 \pm 10$ observations signs of interstitial inflammation, edema of interalveolar membranes with metaplasia of alveolar epithelium and proliferation of fibroblasts were revealed.

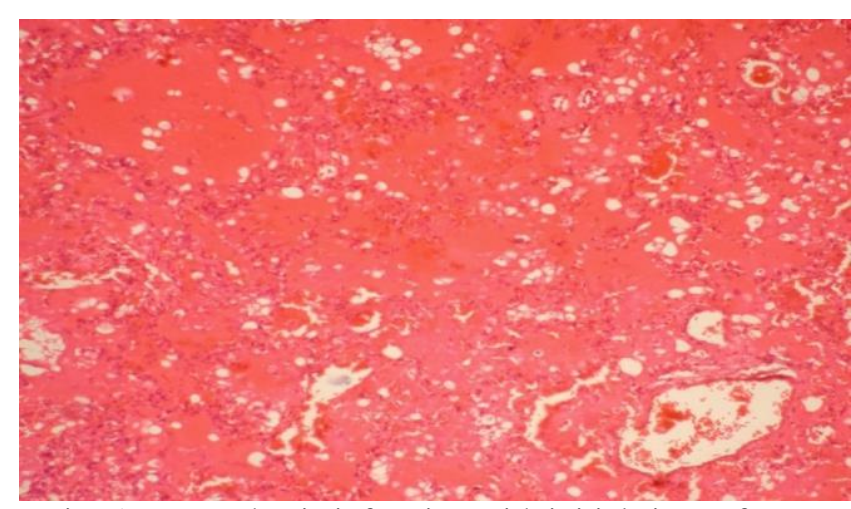

Fig. 5. Hemorrhagic infarction with initial signs of organization. Hematoxylin and eosin staining, magnification $\times 100$

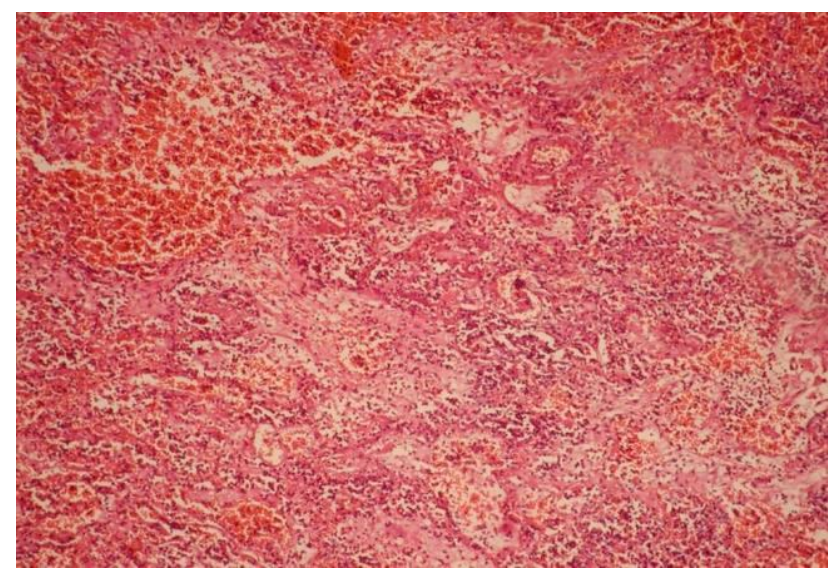

Fig. 6. In the lumen of the alveoli polymorphic cell exudate with admixtures of erythrocytes and fibrin in the stage of organization Staining with hematoxylin and eosin, magnification $\times 100$

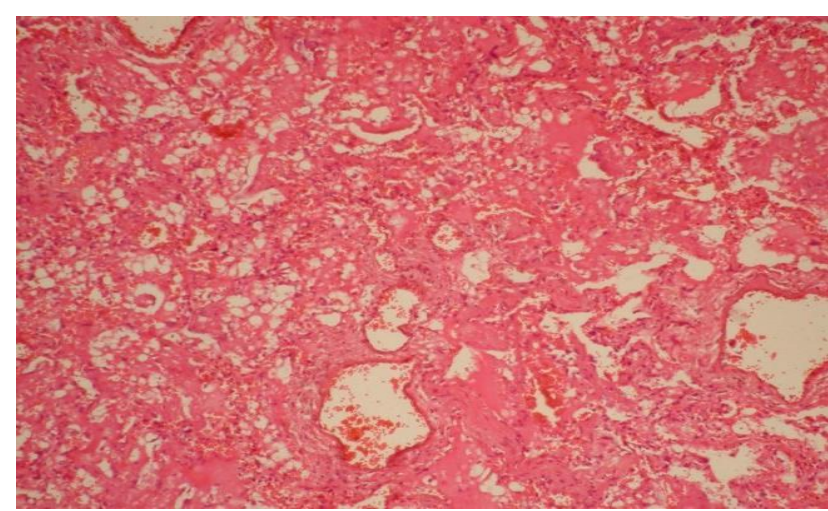

Fig. 7. Area of pneumonia in the stage of organization, violation of the architecture of the alveoli due to fibrosis of the walls, proliferation of fibroblasts and the development of loose granulation tissue. Hematoxylin and eosin staining, magnification $\times 100$

In $50 \pm 17 \%$ of observations along with signs pneumonia was found bacterial focal, in some places draining, purulent bronchopneumonia with fibrinouspurulent pleurisy (Fig. 8). 


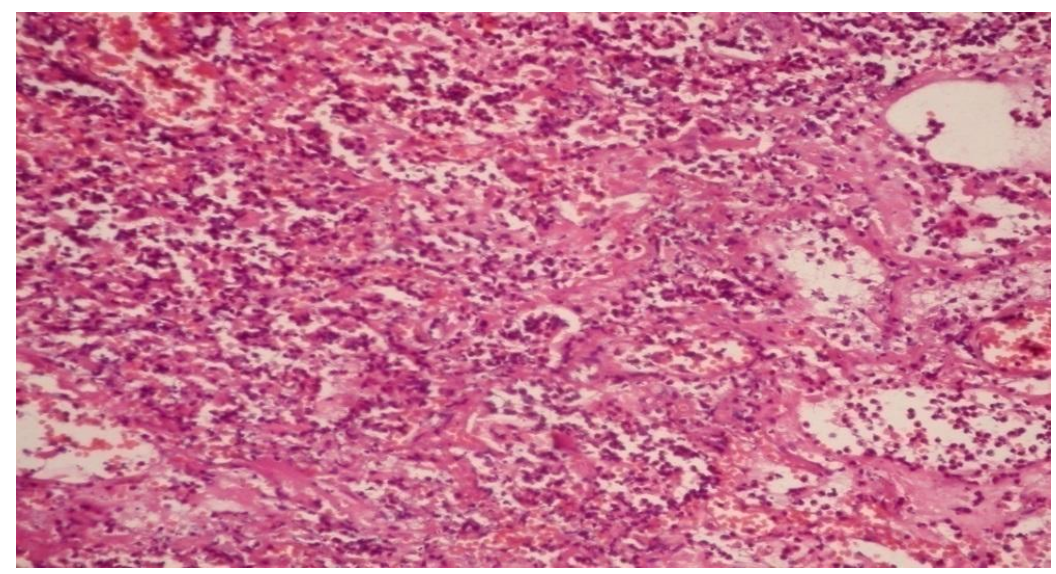

Fig. 8. Area of focal purulent pneumonia with accumulation in the lumen of the alveoli of a large number of neutrophils and fibrin on the background of sharp plethora of the microcirculatory tract. Hematoxylin and eosin staining, magnification $\times 200$

In addition, in some cases, there were signs of focal bacterial pneumonia due to the accession of second- ary infection, especially during prolonged stay in ICU (Table 7).

Table 7

Comparative characteristics of morphological changes of lung tissue in patients of the examined groups ( $\mathrm{P} \pm \mathrm{Sp}$ )

\begin{tabular}{|c|c|c|}
\hline Morphological changes & Group 1 & Group 2 \\
\hline Edematous hemorrhagic syndrome & $100.0-10$ & $90.0 \pm 10$ \\
\hline Thromboembolic syndrome & $80.0 \pm 13$ & $80.0 \pm 13$ \\
\hline Interstitial pneumonia with epithelial desquamation & $90.0 \pm 10^{* *}$ & $10.0 \pm 10$ \\
\hline Hyaline membrane formation & $80.0 \pm 13^{*}$ & $10.0 \pm 10$ \\
\hline Proliferation of alveolocytes type II & $80.0 \pm 13$ & $40.0 \pm 16$ \\
\hline Atelectasis and dystelectasis & $30.0 \pm 15$ & $30.0 \pm 15$ \\
\hline Emphysema & $10.0 \pm 10$ & $40.0 \pm 16$ \\
\hline $\begin{array}{l}\text { Interstitial pneumonia with signs of organization by productive } \\
\text { alveolitis }\end{array}$ & $30.0 \pm 15^{*}$ & $90.0 \pm 10$ \\
\hline Fibrosing alveolitis & $10.0 \pm 10 * *$ & $90.0 \pm 10$ \\
\hline Bacterial pneumonia & $0.0+10^{*}$ & $50.0 \pm 17$ \\
\hline
\end{tabular}

Note: $*-p<0.05 ; * *-p<0.001$

\section{Discussion}

According to Zabolzaev F. G. the course of ARDS in COVID-19 has three stages that accompany the development of the corresponding clinical and morphological phases of lung damage in coronavirus disease [29].

1. Exudative stage with the development of the fulminant phase of COVID-19 interstitial pneumonia

2. Proliferative stage with the development of persistent phase COVID-19 interstitial pneumonia

3 . Fibrotic stage with the development of the fibrotic phase of COVID-19 interstitial pneumonia

Each of these stages develops at different time intervals and is characterized by corresponding macro- and microscopic features.

The exudative stage corresponds to the acute phase (DAD) with the development of widespread pulmonary edema and the formation of hyaline membranes in the future. The described stage usually develops within 10 days from the onset of the disease.

The peculiarity of the proliferative phase (up to 20 days from the onset of the disease) is a wide range of morphological changes, constant combination of persis- tent signs of exudative stage with hyperplastic, reactive and dysregenerative changes fibrosis.

Morphological signs of the fibrotic stage (2145 days of the disease) are accompanied by dysregenerative metaplastic and dysplastic changes, multiplicative forced effect of fibrosis and fibrotic remodelling of lung tissue.

In our study, lung groups were characterized by changes in thromboembolic syndrome with the development of the pattern of DAP.

The morphological structure of the lungs of patients in group 1 corresponded to the exudative phase of DAD with severe edematous-hemorrhagic syndrome, signs of interstitial pneumonia with desquamation of alveolocytes and hyaline formation. It should be noted that the observations of this group drew attention not only to the severity of edema-hemorrhagic syndrome, but also the inconsistency of the classical stages of diffuse alveolar damage of the duration of the disease. Thus, in some observations, changes in the lungs characteristic of the early exudative stage were detected after 14 days from the onset of the disease in the absence of changes characteristic of the 
late proliferative stage. Signs of interstitial pneumonia with the formation of fibrosing alveolitis were observed in only $10 \%$ of patients.

In patients of group 2 in the lung tissue there was a picture of the proliferative phase of DAD with signs of interstitial pneumonia, thickening of the alveolar membranes due to mononuclear infiltration and interstitial fibrosis and the development of focal fibrosing alveolitis. In addition, in some cases, signs of focal bacterial and draining bronchopneumonia due to the accession of secondary bacterial infection, especially in patients with prolonged stay on mechanical ventilation. Thus, we can think that invasive mechanical ventilation, in contrast to non-invasive CPAP, can accelerate the development of irreversible processes in the lungs in the form of fibrosing alveolitis and promote the formation of ventilator-associated pneumonia.

Study limitations. The limitations of the study are related to a small sample of patients.

Prospects for further study. The study of the effect of ventilation regimens in patients with moderate and severe ARDS caused by SARS-nCoV-2 virus (COVID-19) on the morphological structure of the lungs will be further developed.

\section{Conclusions.}

1. In patients with severe SARS-nCoV-2 (COVID-19), with the development of moderate and severe ARDS, the use of non-invasive ventilation in the CPAP mode allows to maintain adequate oxygenation $\left[\mathrm{SpO}_{2} 94.0\right.$ [92.0-96.0] \% ) and does not differ significantly in this respect from invasive ventilation $\left(\mathrm{SpO}_{2} 94.0\right.$ [93.0-97.0] \%) ( $\left.\mathrm{p}>0.05\right)$.

2. The incidence of interstitial pneumonia with epithelial desquamation was $90.0 \pm 10 \%$ in group 1 and was significantly higher than in group $2(\mathrm{p}<0.001)$.

3 . In group 2 there was a significantly higher frequency of bacterial complications than in group 1 $(50.0 \pm 17 \%, \mathrm{p}<0.05)$.

4. The incidence of fibrotic changes in group 2 was $90.0 \pm 10 \%$ and was significantly higher than in group $1(\mathrm{p}<0.05)$.

5 . The most favorable morphological picture was obtained in group 1 where patients were on non-invasive lung ventilation in CPAP mode. Therefore, it is possible to draw preliminary conclusions about the benefits and potential feasibility of using this mode of ventilation support.

\section{Conflict of interests}

The authors declare there is no conflict of interests.

\section{Financing}

The study was performed without financial support.

\section{References}

1. Ruan, Q., Yang, K., Wang, W., Jiang, L., Song, J. (2020). Correction to: Clinical predictors of mortality due to COVID-19 based on an analysis of data of 150 patients from Wuhan, China. Intensive Care Medicine, 46 (6), 1294-1297. doi: http://doi.org/10.1007/s00134020-06028-Z

2. Bellani, G., Laffey, J. G., Pham, T., Madotto, F., Fan, E., Brochard, L. et. al. (2017). Noninvasive Ventilation of Patients with Acute Respiratory Distress Syndrome. Insights from the LUNG SAFE Study. American Journal of Respiratory and Critical Care Medicine, 195 (1), 67-77. doi: http://doi.org/10.1164/rccm.201606-1306oc

3. Intensive Care National Audit \& Research Centre (ICNARC) (2020). ICNARC report on COVID-19 in critical care. Available at: https://www.icnarc.org/DataServices/Attachments/Download/c31dd38d-d77b-ea11-9124-00505601089b

4. Richardson, S., Hirsch, J. S., Narasimhan, M., Crawford, J. M., McGinn, T. et. al. (2020). Presenting Characteristics, Comorbidities, and Outcomes Among 5700 Patients Hospitalized With COVID-19 in the New York City Area. JAMA, 323 (20), 2052. doi: http://doi.org/10.1001/jama.2020.6775

5. Hua, J., Qian, C., Luo, Z., Li, Q., Wang, F. (2020). Invasive mechanical ventilation in COVID-19 patient management: the experience with 469 patients in Wuhan. Critical Care, 24 (1). doi: http://doi.org/10.1186/s13054-020-03044-9

6. Rochwerg, B., Brochard, L., Elliott, M. W., Hess, D., Hill, N. S., Nava, S. et. al. (2017). Official ERS/ATS clinical practice guidelines: noninvasive ventilation for acute respiratory failure. European Respiratory Journal, 50 (2), 1602426. doi: http://doi.org/10.1183/13993003.02426-2016

7. Avdeev, S. N. (2018). Noninvasive ventilation in acute respiratory failure: from clinical guidelines to the real clinical practice. Commentary on Clinical guidelines on use of noninvasive ventilation in patients with acute respiratory failure. Russian Pulmonology, 28 (1), 32-35. doi: http://doi.org/10.18093/0869-0189-2018-28-1-32-35

8. Avdeev, S. N. (2005). Non-invasive ventilation in acute respiratory failure. Pulmonologiya, 6, 37-54. doi: http://doi.org/10.18093/ 0869-0189-2005-0-6-37-54

9. Crimi, C., Noto, A., Cortegiani, A., Impellizzeri, P., Elliott, M., Ambrosino, N., Gregoretti, C. (2020). Noninvasive respiratory support in acute hypoxemic respiratory failure associated with COVID-19 and other viral infections. doi: http://doi.org/10.1101/2020.05.24.20111013

10. L'Her, E., Deye, N., Lellouche, F., Taille, S., Demoule, A., Fraticelli, A. et. al. (2005). Physiologic Effects of Noninvasive Ventilation during Acute Lung Injury. American Journal of Respiratory and Critical Care Medicine, 172 (9), 1112-1118. doi: http://doi.org/10.1164/ rccm.200402-226oc

11. Morais, C. C. A., Koyama, Y., Yoshida, T., Plens, G. M., Gomes, S., Lima, C. A. S. et. al. (2018). High Positive EndExpiratory Pressure Renders Spontaneous Effort Noninjurious. American Journal of Respiratory and Critical Care Medicine, 197 (10), 1285-1296. doi: http://doi.org/10.1164/rccm.201706-1244oc

12. Brambilla, A. M., Aliberti, S., Prina, E., Nicoli, F., Forno, M. D., Nava, S. et. al. (2014). Helmet CPAP vs. oxygen therapy in severe hypoxemic respiratory failure due to pneumonia. Intensive Care Medicine, 40 (7), 942-949. doi: http://doi.org/10.1007/s00134-014$3325-5$

13. Grieco, D. L., Menga, L. S., Eleuteri, D., Antonelli, M. (2019). Patient self-inflicted lung injury: implications for acute hypoxemic respiratory failure and ARDS patients on non-invasive support. Minerva Anestesiologica, 85 (9). doi: http://doi.org/10.23736/s03759393.19.13418-9 
14. Lefebvre, J.-C., Cordioli, R., Akoumianaki, E., Richard, J.-C., Brochard, L. (2014). Noninvasive Ventilation for Patients with Hypoxemic Acute Respiratory Failure. Seminars in Respiratory and Critical Care Medicine, 35 (4), 492-500. doi: http://doi.org/10.1055/s0034-1383863

15. Demoule, A., Chevret, S., Carlucci, A., Kouatchet, A., Jaber, S. (2015). Changing use of noninvasive ventilation in critically ill patients: trends over 15 years in francophone countries. Intensive Care Medicine, 42 (1), 82-92. doi: http://doi.org/10.1007/s00134-015-4087-4

16. Duca, A., Memaj, I., Zanardi, F., Preti, C., Alesi, A., Della Bella, L. et. al. (2020). Severity of respiratory failure and outcome of patients needing a ventilatory support in the Emergency Department during Italian novel coronavirus SARS-CoV2 outbreak: Preliminary data on the role of Helmet CPAP and Non-Invasive Positive Pressure Ventilation. EClinicalMedicine, 24. doi: http://doi.org/10.1016/ j.eclinm.2020.100419

17. Pagano, A., Porta, G., Bosso, G., Allegorico, E., Serra, C., Dello Vicario, F. et. al. (2020). Non-invasive CPAP in mild and moderate ARDS secondary to SARS-CoV-2. Respiratory Physiology \& Neurobiology, 280. doi: http://doi.org/10.1016/j.resp.2020.103489

18. Nightingale, R., Nwosu, N., Kutubudin, F., Fletcher, T., Lewis, J., Frost, F. et. al. (2020). Is continuous positive airway pressure (CPAP) a new standard of care for type 1 respiratory failure in COVID-19 patients? A retrospective observational study of a dedicated COVID-19 CPAP service. BMJ Open Respiratory Research, 7 (1). doi: http://doi.org/10.1136/bmjresp-2020-000639

19. Burns, G. P., Lane, N. D., Tedd, H. M., Deutsch, E., Douglas, F., West, S. D. et. al. (2020). Improved survival following ward-based non-invasive pressure support for severe hypoxia in a cohort of frail patients with COVID-19: retrospective analysis from a UK teaching hospital. BMJ Open Respiratory Research, 7 (1). doi: http://doi.org/10.1136/bmjresp-2020-000621

20. Aliberti, S., Radovanovic, D., Billi, F., Sotgiu, G., Costanzo, M., Pilocane, T. et. al. (2020). Helmet CPAP treatment in patients with COVID-19 pneumonia: a multicentre cohort study. European Respiratory Journal, 56 (4). doi: http://doi.org/10.1183/13993003.019352020

21. Franco, C., Facciolongo, N., Tonelli, R., Dongilli, R., Vianello, A., Pisani, L. et. al. (2020). Feasibility and clinical impact of out-of-ICU noninvasive respiratory support in patients with COVID-19-related pneumonia. European Respiratory Journal, 56 (5), 2002130. doi: http://doi.org/10.1183/13993003.02130-2020

22. Mukhtar, A., Lotfy, A., Hasanin, A., El-Hefnawy, I., El Adawy, A. (2020). Outcome of non-invasive ventilation in COVID-19 critically ill patients: A Retrospective observational Study. Anaesthesia Critical Care \& Pain Medicine, 39 (5), $579-580$. doi: http://doi.org/10.1016/j.accpm.2020.07.012

23. McLaughlin, K. M., Murray, I. M., Thain, G. et. al. (2010). Wardbased noninvasive ventilation for hypercapnic exacerbations of COPD: a "real-life" perspective. QJM, 103 (7), 505-510. doi: http://doi.org/10.1093/qjmed/hcq063

24. Orhanizatsiia nadannia medychnoi dopomohy khvorym na koronavirusnu khvorobu (COVID-19) (2020). Nakaz MOZ Ukrainy No. 722. 28.03.2020. Available at: https://moz.gov.ua/article/ministry-mandates/nakaz-moz-ukraini-vid-28032020--722organizacija-nadannja-medichnoi-dopomogi-hvorim-na-koronavirusnu-hvorobu-covid-19

25. Pro zatverdzhennia protokolu «Nadannia medychnoi dopomohy dlia likuvannia koronavirusnoi khvoroby (COVID-19) (2020). Nakaz MOZ Ukrainy No. 762. 02.04.2020. Available at: https://zakon.rada.gov.ua/rada/show/v0762282-20\#Text

26. Pro vnesennia zmin do protokolu «Nadannia medychnoi dopomohy dlia likuvannia koronavirusnoi khvoroby (COVID19) (2020). Nakaz MOZ Ukrainy No. 852. 10.04.2020. Available at: https://zakon.rada.gov.ua/rada/show/v0852282-20\#Text

27. Pro vnesennia zmin do dodatku 6 Standartiv medychnoi dopomohy Koronavirusna khvoroba (COVID-19) (2020). Nakaz MOZ Ukrainy No. 994. 30.04.2020. Available at: https://moz.gov.ua/article/ministry-mandates/nakaz-moz-ukraini-vid-30042020-994-pro-vnesennja-zmin-do-dodatku-6-do-standartiv-medichnoi-dopomogi-koronavirusna-hvoroba-covid-19

28. Pro vnesennia zmin do Standartiv medychnoi dopomohy Koronavirusna khvoroba (COVID-19) (2020). Nakaz MOZ Ukrainy No. 1411. 16.06.2020. Available at: https://moz.gov.ua/article/ministry-mandates/nakaz-moz-ukraini-vid-16062020--1411pro-vnesennja-zmin-do-standartiv-medichnoi-dopomogi-koronavirusna-hvoroba-covid-19

29. Zabozlaev, F. G., Kravchenko, E. V., Gallyamova, A. R., Letunovskiy, N. N. (2020). Pulmonary pathology of new coronavirus disease (COVID-19). the preliminary analysis of post-mortem findings. Journal of Clinical Practice, 11 (2), 21-37. doi: http://doi.org/10.17816/clinpract34849

Received date 20.05.2021

Accepted date 22.06.2021

Published date 30.07.2021

Vita Skoryk, Department of Anesthesiology, Pediatric Anesthesiology and Intensive Care, Kharkiv Medical Academy of Postgraduate Education, Amosova str., 58, Kharkiv, Ukraine, 61176

Volodymyr Korsunov, Doctor of Medical Sciences, Professor, Department of Anesthesiology, Pediatric Anesthesiology and, Intensive Care, Kharkiv Medical Academy of Postgraduate Education, Amosova str., 58, Kharkiv, Ukraine, 61176

Tetiana Bocharova, PhD, Associate Professor, Department of Pathological Anatomy, Kharkiv National Medical University, Nauky ave., 4, Kharkiv, Ukraine, 61022

Pavel Nartov, Doctor of Medical Sciences, Professor, Department of Infectious Diseases, Kharkiv Medical Academy of Postgraduate Education, Amosova str., 58, Kharkiv, Ukraine, 61176

Valentina Maslova, PhD, Associate Professor, Department of Infectious Diseases, Kharkiv Medical Academy of Postgraduate Education, Amosova str., 58, Kharkiv, Ukraine, 61176

*Corresponding author: Vita Skoryk, e-mail: vitaskoryk@gmail.com 